\title{
First record of the Tadpole Shrimp Triops cancriformis (Branchiopoda, Notostraca) in Cyprus
}

\author{
Iakovos Tziortzis ${ }^{1, *}$, Stamatis Zogaris ${ }^{2}$, Athena Papatheodoulou ${ }^{3}$ and Federico Marrone ${ }^{4}$ \\ ${ }^{1}$ Enalia Physis Environmental Research Center, Akropoleos 2 Aglantzia 2101, Nicosia, Cyprus. \\ ${ }^{2}$ Institute of Marine Biological Resources and Inland Waters, Hellenic Centre for Marine Research, 46,7 km \\ Athens-Sounio, Anavissos, Attiki, GR-19013 Greece. \\ ${ }^{3}$ Biodiversity East, P.O. Box 56657, 3309, Limassol, Cyprus. \\ ${ }^{4}$ Dipartimento di Scienze e Tecnologie Biologiche, Chimiche e Farmaceutiche, Sezione di Biologia Animale ed \\ Antropologia Biologica, Università di Palermo, via Archirafi 18, I-90123 Palermo, Italy. \\ * Corresponding author: i.tziortzis@enaliaphysis.org.cy
}

Received: 05/05/2014

Accepted: 16/09/2014

\begin{abstract}
First record of the Tadpole Shrimp Triops cancriformis (Branchiopoda, Notostraca) in Cyprus

The presence of the large branchiopod Triops cancriformis (Bosc, 1801-1802) in Cyprus is reported for the first time. Triops cancriformis individuals were observed in the large temporary wetland of Paralimni Lake (Famagusta District, Cyprus) during the wet periods of 2013 and 2014. This finding extends the current knowledge of the species distribution in the eastern Mediterranean area and stresses the ecological and conservation value of the unique habitat of Paralimni Lake. In addition, it highlights the need to conduct further studies on the fauna of temporary pond habitats in Cyprus and the need to implement better conservation management strategies for this EU priority habitat.
\end{abstract}

Key words: Mediterranean temporary ponds, Paralimni Lake, Notostraca, Branchiopoda, molecular identification.

\section{RESUMEN}

Primer registro de Triops cancriformis (Branchiopoda, Notostraca) en Chipre

Se reporta por primera vez, la presencia del braquiópodo Triops cancriformis (Bosc, 1801-1802) en Chipre. Se detectaron individuos de T.cancriformis en el gran humedal temporal del lago Paralimni (Distrito de Famagusta, Chipre) durante los períodos de lluvia de 2013 y 2014. Este hallazgo amplía el conocimiento actual de la distribución de esta especie en el área del Mediterráneo oriental, y hace hincapié en el valor ecológico y la conservación del hábitat singular del lago Paralimni. Además, pone de relieve la necesidad de seguir estudiando la fauna de lagunas temporales en Chipre con el objetivo de mejorar su gestión para la conservación de dichos hábitats catalogados como prioritarios de la UE.

Palabras clave: Lagunas temporales mediterráneas, Lago Paralimni, Notostraca, Branchiopoda, identificación molecular.

\section{INTRODUCTION}

The order Notostraca (Crustacea, Branchiopoda) includes the family Triopsidae, which is represented by two extant genera: Triops Schrank, 1803 and Lepidurus Leach, 1819. Both genera are often considered as prime examples of "living fossils" (King \& Hanner, 1998; but also see Mathers et al., 2013) with a history dating back to the late Devonian period (Wallossek, 1993; Korn et al., 2013). Due to their minimal morphological changes over geologic time, they 
are often considered as the ultimate example of evolutionary stasis (King \& Hanner, 1998). Tadpole shrimps have a near-worldwide distribution, but due to their ecological specialisation, they mainly occur in temporary water bodies where they can survive long dry periods by laying and deposing resistant cysts in the sediment that remain viable after long periods of diapause. Shortly after hydration, nauplius larvae hatch and develop new populations. In fact, along with other large branchiopods, they are considered as flagship species of aquatic temporary pond and pool habitats. Both genera of the Triopsidae family are found in freshwater, brackish and occasionally saline, temporary pond habitats (Damgaard \& Olesen, 1998; Brendonck et al., 2008), usually only when vertebrate predators are absent (Dumont \& Negrea, 2002; Ruiz, 2008).

Triops species have a scattered but cosmopolitan distribution including all continents except Antarctica (Vanschoenwinkel et al., 2012; Korn et al., 2013). In the Mediterranean region, Triops granarius (Lucas, 1864) and at least 7 different taxa formerly attributed to Triops cancriformis sensu latu are known to occur (Korn et al., 2006; 2010; Korn \& Hundsdoerfer, 2006).

Notostracan presence and distribution is relatively well known in the countries of the western Mediterranean area, from the Iberian Peninsula to southern France and Italy (including the Balearic Islands, Sicily, Sardinia and Corsica), the entire Maghreb, and Malta (e.g.: Brtek \& Thiéry, 1995; Alonso, 1996; Grillas et al., 2004; Marrone et al., 2006; Vanschoenwinkel et al., 2012). Conversely, only scarce and scattered data are available for the countries of the eastern Mediterranean area. Here, the absence of records from some larger islands, such as Cyprus and Crete, and from extensive areas of the Hellenic Peninsula, where the presence of Triops cancriformis (Bosc, 1801-1802) has only been reported from limited locations in Greece (Colosi, 1923; Kazantzidis \& Goutner, 2005), is likely to be attributed to the lack of sufficient research on the biota of temporary water bodies, i.e., the required habitat of the notostracans rather than the actual absence of Notostraca in the area. In fact, it is widely accepted that the

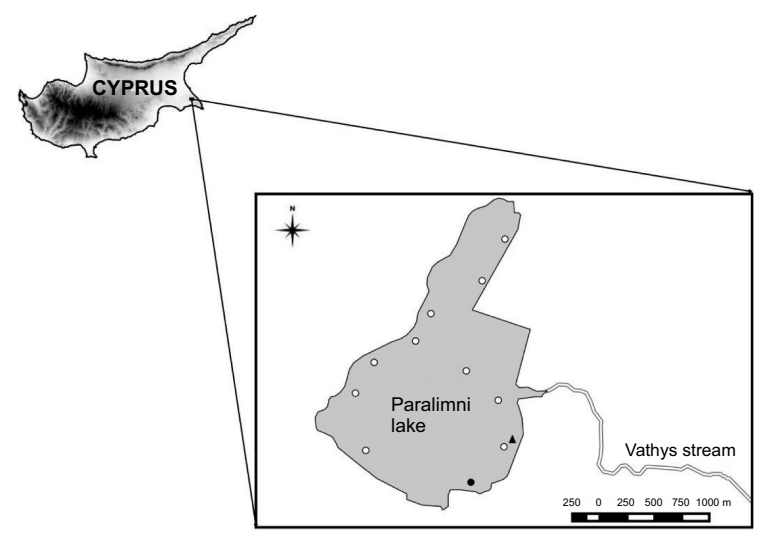

Figure 1. Paralimni Lake location in Cyprus and the areas investigated during 2013-2014 sampling campaigns. The full triangle indicates the 2013 record of $T$. cancriformis; the full circle indicates the record of 2014. Empty circles indicate the areas surveyed in 2014 with no results. Localización del Lago Paralimni en Chipre y las áreas de estudio durante los muestreos de 2013 y 2014. El triangulo indica donde se encontró el registro de 2013, el círculo el de 2014. Los círculos blancos indican las zonas muestreadas en 2014 sin resultados.

known distribution of certain "less charismatic" aquatic taxa better reflects the distribution of their specialists than the actual distribution of those taxa themselves. Knowledge gaps of specialised crustaceans dwelling in temporary water habitats in the eastern Mediterranean area weakens our understanding of the natural history of the inland water biota of the Western Palaearctic biogeographical region. A sampling campaign investigating the inland water bodies of Cyprus is thus currently underway with the aim of describing the crustacean biota of the island. This paper presents the first record of the tadpole shrimp Triops cancriformis in the island of Cyprus, found in a NATURA 2000 temporary wetland. In addition, we compare the taxonomical concordance with other specimens from Europe using the molecular identification of mitochondrial DNA.

\section{MATERIALS AND METHODS}

\section{Study area}

Cyprus is located at the eastern edge of the Mediterranean Sea, and it is characterised by a long, dry summer and a relatively wet, mild 
winter. The mean annual temperature and precipitation values reach $17.7^{\circ} \mathrm{C}$ and $465 \mathrm{~mm}$, respectively, and both parameters are characterised by high deviation between winter and summer period. The semi-arid climatic conditions result in the scarcity of perennial natural wetlands and favour the presence of a number of seasonal shallow water bodies throughout the island. Some of these are suitable habitats for crustaceans that have developed strategies to survive in such seasonally desiccated environments (Marrone et al., 2006; Brendonck et al., 2008; Vanschoenwinkel et al., 2010). Paralimni Lake (Latitude: $35.038300^{\circ} \mathrm{N}$, Longitude: $33.968300^{\circ} \mathrm{E}$ ) is a slightly brackish, shallow temporary water body with an average depth of $15 \mathrm{~cm}$ during the wet period. It is located in the southeastern part of the island and covers a total area of approximately 273 ha (Fig. 1). It is the largest natural inland lake on the island and has been included in the EU NATURA 2000 protected areas network under the Habitats Directive (Council Directive 92/43/EEC). Until recently, this wetland had been unjustly overlooked because most of the lake area is often totally desiccated. However, the attention of nature conservationists has been attracted by the presence of endemic priority species such as the Cyprus grass snake Natrix natrix cypriaca (Hecht, 1930), one endemic plant species, two species listed in the Red Data Book of the flora of Cyprus and over one hundred bird species, many of which are wading birds that feed on crustaceans (Iezekiel et al., 2004; Tsintides et al., 2007; Blosat, 2008). Due to the temporary nature of the lake, no fish species are present in the lake, and this is assumed to facilitate the presence of large branchiopods. Vegetation is dominated by halophilus species such as Salicornia sp. and other annuals colonising mud and sand (Habitat 1310), whereas the wet areas are mainly covered by habitat type 1410-Mediterranean salt meadows (Juncetalia maritimi). Small man-made depressions with prolonged periods of water presence host submerged aquatic macrophytes such as Ruppia maritima, Zannichellia pallustris and Chara spp. (personal observations). The wetland is part of a wide endorheic system in which water from the drainage area of the ephemeral Vathys stream network, coupled with inflows of the overall drainage area of the lake, accumulates during wet winters in a non-permeable lake depression. This shallow lake has a temporary hydroperiod and naturally dries up periodically. Drainage engineering works have degraded its natural flooding regime since the early $20^{\text {th }}$ century (Georgis, 2008). Despite its ecological importance, Paralimni Lake still suffers from illegal dumping and infilling, illegal water abstraction, poor water management practices and habitat degradation, which have an overall impact on the wetland and its riparian zone.

\section{Sampling and morphological identification}

During a field survey carried out in early March 2013, following a high-precipitation winter season that resulted in an unusually high water level in the lake, several carcasses ( 0 to 10 carapaces $/ \mathrm{m}^{2}$ ) of recently deceased notostracans were observed at the east shore of Paralimni Lake (Fig. S1a and S1b, Supplementary information available at www.limnetica.net/internet). At the time of sampling, the water had recently been withdrawn from the shore due to a swift outflow of water from the lake, and this probably caused the en masse death of the tadpole shrimps.

The winter period of early 2014 was unusually dry; as a result, the lake did not experience a high-water flooding phase. Water accumulated only in small, shallow pools that were scattered in various isolated parts of the wetland basin. Several sampling attempts were made in January, February and March 2014 to locate Triops cancriformis populations. Overall, a total of eleven pools of different sizes and depths were surveyed (Fig. 1). Sampling was carried out with a $200 \mathrm{mi}-$ cron mesh-sized hand net; qualitative crustacean samples were collected paying specific attention to sample every micro-habitat present in the surveyed pools. Furthermore, notostracans were actively searched for when possible due to the water transparency. Collected samples were fixed in situ in $80 \%$ ethanol and sorted in the laboratory using a stereomicroscope ZEISS Stemi 2000-C. When present, notostracans were sorted 
and identified based on morphology according to Longhurst (1955), Alonso (1996), and Korn et al. (2006, 2010).

The collected samples are now stored in FM's crustacean collections at the Section of Animal Biology and Biological Anthropology of the department STEBICEF, University of Palermo, where they are available for loan upon request.

\section{DNA extraction, amplification, and sequencing}

It is well known that the noteworthy morphological bradytely of the representatives of the family Triopsidae hampers the taxonomy of the taxon and may prevent a sound identification of the taxa based on morphology alone (e.g.: Korn et al., 2006; Scanabissi et al., 2006). Accordingly, a fragment of the mitochondrial DNA $12 \mathrm{~S}$ gene was amplified in the collected specimen to carry out the molecular identification of the Triops taxon occurring in Cyprus.

Prior to DNA extraction, the single available specimen was carefully cleaned under the stereomicroscope. Two thoracopods were cut and soaked in double-distilled water for $3 \mathrm{~h}$. DNA was then extracted from the thoracopods following the "DNeasy-Animal Tissue Kit" (QIAGEN) protocol.

A fragment of the 12S mtDNA gene was amplified following the protocol described in Korn et al. (2006). PCR product was purified using

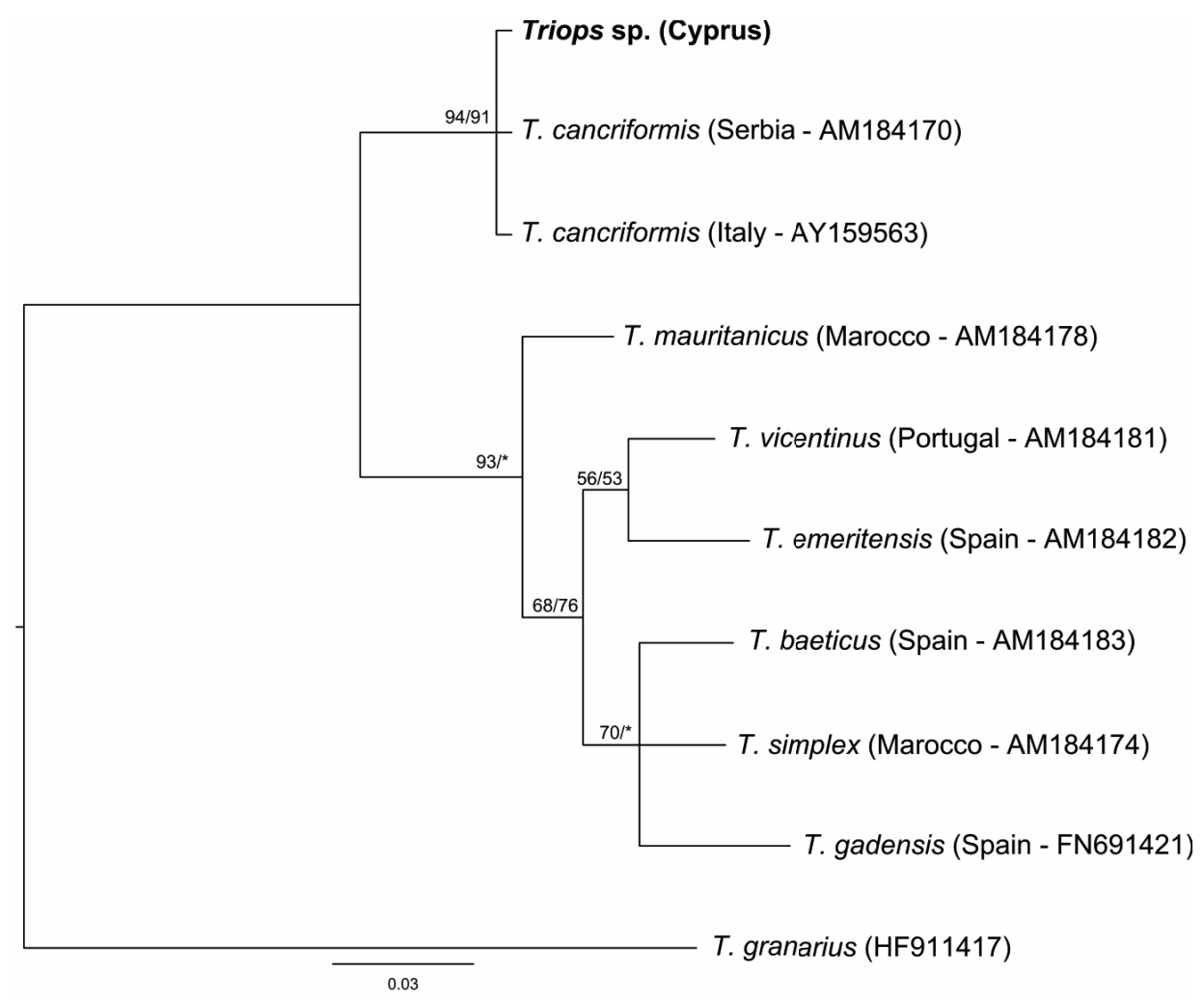

Figure 2. Bayesian phylogram (ngen $=2,000,000$; nchains $=4$; nrun $=2$; samplefreq $=100$; temp $=0.2$; default priors) of the mitochondrial small subunit ribosomal DNA (mtDNA 12S) Triops dataset rooted on Triops granarius. Node support is reported as nodal posterior probabilities/ML bootstrap. “*” indicates bootstrap support lower than 50 . Origin and GenBank accession numbers are provided in the brackets for non-novel haplotypes. T. vicentinus, T. emeritensis, T. baeticus, T. simplex and T. gadensis sequences are mislabelled as "Triops mauritanicus" in GenBank. Árbol filogenético basado en inferencia Bayesiana del gen mitocondrial mtDNA $12 S$ del espécimen de Triops encontrado. (*) Indica el soporte de cada rama del árbol con valores de bootstrap <50. Se utilizó la base de datos GenBank (números entre paréntesis) para los haplotipos conocidos. Las secuencias de T. vicentinus, T. emeritensis, T. baeticus, T. simplex and T. gadensis están consideradas dentro de "Triops mauritanicus” en GenBank. 
the Exo-SAP-IT kit and sequenced with an ABI 3130xL (Applied Biosystems) sequencer. The forward primers were used for direct sequencing of the PCR product, and the quality of the produced sequence was checked with the Applied Biosystems Sequence Scanner v1.0 software.

Nine $12 \mathrm{~S}$ sequences belonging to all the currently known west Palaearctic Triops species were downloaded from GenBank (Accession Numbers reported in Fig. 2) and aligned with BioEdit (Hall, 1999). The novel Cyprus Triops sequence was deposited in GenBank.

Bayesian (BA) and Maximum Likelihood (ML) analyses were performed as implemented in MrBayes 3.1.2 (Huelsenbeck \& Ronquist, 2001) and PhyMl v.3 (Guindon \& Gascuel, 2003), respectively. As a measure of branch support, bootstrap values were calculated with 1000 replicates in the ML analysis. The node support of BA trees was evaluated by their posterior probabilities. For both Maximum Likelihood and Bayesian analyses, the best evolutionary model for implementation was selected using mrModeltest 2.2 (Nylander, 2004).

\section{RESULTS AND DISCUSSION}

In March 2013, no Triops specimens were found alive, and extensive sampling efforts to locate live individuals in the shallow waters and the area surrounding the lake yielded no specimens. However, the size of three dead individuals was measured. The mean standard body length (carapace anterior tip to telson posterior tip) and carapace length (measured along the median ridge) was $44 \mathrm{~mm}$ and $30 \mathrm{~mm}$, respectively. These values were found to be close to the values reported for Triops cancriformis from Lithuania (Matulaitis, 2007) and the Iberian Peninsula (Machado et al., 1999).

Despite the high abundance of Triops carcasses observed in March 2013, the winter $2013 / 2014$ survey led to the finding of a single, small-sized Triops specimen during the sampling campaign of January 21 2013 (Fig. S1c, Supplementary information available at www. limnetica.net/internet). The standard body length of this specimen measured $13 \mathrm{~mm}$, and the carapace length was $7 \mathrm{~mm}$. The specimen was an egg-bearing individual that could be identified as Triops cancriformis s.l. based on morphology.

The PCR produced a high-quality sequence of a 580 bp long $12 \mathrm{~S}$ fragment. Upon its alignment with the Triops sequences downloaded from GenBank and the trimming of the tails, which were not present in all the individuals, a 348 bp-long alignment was produced. The BA and ML trees produced based on this dataset, showed a concordant topology, which unambiguously placed the Triops sp. sequence from Cyprus within the Triops cancriformis s.s. clade; the 348-bp long $12 \mathrm{~S}$ fragment of the Cyprus specimen proved to be identical to that observed in specimens from Italy and Serbia (Mantovani et al., 2004; Korn et al., 2006). The molecular identification of the specimen thus demonstrated good support of the morphology-based identification, and the $12 \mathrm{~S}$ haplotype scored in the collected specimen could be unambiguously ascribed to Triops cancriformis s.s.

The high number of dead specimens found in Paralimni Lake in March 2013 was unexpected since no previous reports on the presence of this species in Cyprus are available. Nevertheless, high numbers of Cattle Egret (Bubulcus ibis) were observed feeding in the lake during the same period, and this could be explained by the presence of Triops cancriformis (see also Boix et al., 2002). A similar case of Triops cancriformis populations emerging in previously unknown locations after an unusual rainy year was recorded by Machado et al. (1999) in southwestern Portugal.

The apparent low density of $T$. cancriformis in Paralimni Lake in the winter 2013/2014 could possibly be attributed to the extensive drought of the winter period, which resulted in a shorter hydroperiod in the lake and higher salinity values; the latter is known to be a limiting factor for cyst hatching and the survival of Triops species (Scott \& Grigarick, 1979; Su \& Mulla, 2002; Cancela da Fonseca et al., 2008; Waterkeyn et al., 2010).

The discovery of this new species for the fauna of Cyprus is interesting since Notostraca are significant links in the food web, especially 
in seasonally semi-arid wetland systems (Kazantzidis \& Goutner, 2005; Angeler et al., 2008). The inland water crustacean fauna of Cyprus has not been given the appropriate attention to date, and the discovery of Triops cancriformis on the island may be just the tip of the iceberg. The presence of halophilous Anostraca species, such as Artemia salina and Phallocryptus spinosa, in the coastal wetlands of the island has already been reported in the past (Mura \& Hadjistephanou, 1987), but the crustacean fauna of the widespread temporary ponds and vernal pools of the island have been neglected to date. This first finding of Triops cancriformis in Cyprus highlights the need for the commencement of extensive studies in such habitats. Furthermore, the importance of temporary ponds has been recognised by the Cyprus government, which as a member of the European Union since 2003, has undersigned the EU Habitats Directive 92/43/EC in which Mediterranean temporary ponds (code $3170^{*}$ ) are classified as priority habitats for conservation.

Lastly, this record unveils new needs for water and habitat management strategies in Paralimni Lake. In the Mediterranean region, many temporary wetland habitats and associated species have been locally and regionally lost due to excessive anthropogenic pressures (Brown, 1998; Boix et al., 2002; Grillas et al., 2004; Zacharias et al., 2007). At Paralimni Lake, temporary habitats are threatened by inadequate water management practices, which inevitably impact the lake's biota, thus threatening the survival of many local species. The maintenance of the alternating wet and dry phases is fundamental for the survival of specialised species such as Triops cancriformis that have evolved and survived for millions of years under this particular hydrological regime; therefore, proper water management based on the lake reference conditions should be set as a management priority.

\section{ACKNOWLEDGEMENTS}

Michael Korn is warmly acknowledged for the support he provided in choosing the correct
Triops spp. sequences to be downloaded from GenBank.

\section{REFERENCES}

ALONSO, M. 1996. Crustacea, Branchiopoda. In: Fauna Ibérica, vol. 7. RAMOS, M. A. et al. (Eds.). Museo Nacional de Ciencias Naturales. CSIC. Madrid.

ANGELER, D. G., O. VIEDMA, S. SANCHEZCARRILLO \& M. ALVAREZ-COBELAS. 2008. Conservation issues of temporary wetland Branchiopoda (Anostraca, Notostraca: Crustacea) in a semiarid agricultural landscape: What spatial scales are relevant? Biological Conservation, 141: 1224-1234.

BLOSAT, B. 2008. Population status, threats and protection of the Grass snake Natrix natrix cypriaca (Hecht, 1930) on Cyprus. Mertensiella, 17: 246271.

BOIX, D., J. SALA \& R. MORENO-AMICH. 2002. Population dynamics of Triops cancriformis (Crustacea: Branchiopoda: Notostraca) of the Espolla temporary pond in the northeastern Iberian peninsula. Hydrobiologia, 486: 175-183.

BRENDONCK, L., D. C. ROGERS, J. OLESEN, S. WEEKS \& R. HOEH. 2008. Global diversity of large branchiopods (Crustacea: Branchiopoda) in fresh water. Hydrobiologia, 595: 167-176.

BRTEK, J. \& A. THIÉRY. 1995. The geographic distribution of European Branchiopods (Anostraca, Notostraca, Spinicaudata, Laevicaudata). Hydrobiologia, 298: 263-280.

BROWN, K. S. 1998. Vanishing pools taking species with them. Science, 281: 626.

CANCELA DA FONSECA, L., M. CRISTO, M. MACHADO, J. SALA, J. REIS, R. ALCAZAR \& P. BEJA. 2008. Mediterranean temporary ponds in Southern Portugal: key faunal groups as management tools? Pan-American Journal of Aquatic Sciences, 3(3): 304-320.

COLOSI, G. 1923. Note sopra alcuni Eufillopodi. Atti della Societa Italiana di Scienze Naturali e del Museo Civico di Storia Naturale in Milano, 62: 75-80.

DAMGAARD, J. \& J. OLESEN. 1998. Distribution, phenology and status for the larger Branchiopoda (Crustacea: Anostraca, Notostraca, Spinicaudata and Laevicaudata) in Denmark. Hydrobiologia, 337: 9-13. 
DUMONT, H. J. \& S. NEGREA. 2002. Introduction to the class Branchiopoda. Guides to the Identification of the Microinvertebrates of the Continental Waters of the World, 19. Backhuys Publishers.

GEORGIS, G. 2008. Study in the local History. Paralimni at late $19^{\text {th }}$-early $20^{\text {th }}$ century. Proceedings of the $1^{\text {st }}$ conference "Paralimni-History and Culture". January 19-20, 2008. Paralimni, Cyprus: 2956. In Greek.

GRILLAS, P., P. GAUTHIER, N. YAVERCOVSKI \& C. PERENNOU. 2004. Mediterranean Temporary Pools Volume 1-Issues relating to conservation, functioning and management. Station biologique de la Tour du Valat. France.

GUINDON, S., O. GASCUEL. 2003. A simple, fast, and accurate algorithm to estimate large phylogenies by maximum likelihood. Systematic Biology, 52: 696-704.

HALL, T. A. 1999. BioEdit: a user-friendly biological sequence alignment editor and analysis program for Windows 95/98/NT. Nucleic Acids Symposium Series, 41: 95-98.

HUELSENBECK, J. E. \& F. RONQUIST. 2001. MrBayes: Bayesian inference of phylogeny. Biometrics, 17: 754-755.

IEZEKIEL, S., C. MAKRIS, \& A. ANTONIOU. 2004. Important Bird Areas of European Union importance in Cyprus. Nicosia: BirdLife Cyprus.

KAZANTZIDIS, S. \& V. GOUTNER. 2005. The diet of nestlings of three Ardeidae species (Aves, Ciconiiformes) in the Axios Delta, Greece. Belgian Journal of Zoology, 135(2): 165-170.

KING, J. L. \& R. HANNER. 1998. Cryptic species in a "living fossil" lineage: taxonomic and phylogenetic relationships within the genus Lepidurus (Crustacea: Notostraca) in North America. Molecular Phylogenetics and Evolution, 10: 23-36.

KORN, M. \& A. K. HUNDSDOERFER. 2006. Evidence for cryptic species in the tadpole shrimp Triops granarius (Lucas, 1864) (Crustacea: Notostraca). Zootaxa, 1257: 57-68.

KORN, M., A. J. GREEN, M. MACHADO, J. GARCÍA DE LOMAS, M. CRISTO, L. CANCELA DA FONSECA, D. FRISCH, J. L. PÉREZ-BOTE \& A. K. HUNDSDOERFER. 2010. Phylogeny, molecular ecology and taxonomy of southern Iberian lineages of Triops mauritanicus (Crustacea: Notostraca). Organisms Diversity \& Evolution, 10: 409-440.

KORN, M., F. MARRONE, J. L. PÉREZ-BOTE, M. MACHADO, M. CRISTO, L. CANCELA DA
FONSECA \& A. K. HUNDSDOERFER. 2006. Sister species within the Triops cancriformis lineage (Crustacea, Notostraca). Zoologica Scripta, 35: 301-322.

KORN, M., N. RABET, H. V. GATE, F. MARRONE \& A. K. HUNDSDOERFER. 2013. Molecular phylogeny of the Notostraca. Molecular Phylogenetics and Evolution, 69: 1159-1171.

LONGHURST, A. R. 1955. A review of the Notostraca. Bulletin of the British Museum (Natural History). Zoology, 3: 1-57.

MACHADO, M., M. CRISTO, J. REIS \& L. CANCELA DA FONSECA. 1999. Biological data on Triops cancriformis mauritanicus (Ghigi,1921) and Cyzicus grubei (Simon, 1886) -Crustacea, Branchiopoda- in SW Portugal temporary ponds. Limnetica, 16: 1-7.

MANTOVANI, B., M. CESARI \& F. SCANABISSI. 2004. Molecular taxonomy and phylogeny of the 'living fossil' lineages Triops and Lepidurus (Branchiopoda: Notostraca). Zoologica Scripta, 33: 367-374.

MARRONE, F., R. BARONE \& L. NASELLI FLORES. 2006. Ecological characterization and cladocerans, calanoid copepods and large branchiopods of temporary ponds in a Mediterranean island (Sicily, Southern Italy). Chemistry \& Ecology, 22: 176-190.

MATHERS, T. C., HAMMOND R. L., JENNER, R. A., HÄNFLING B. \& A. GOMEZ. 2013. Multiple global radiations in tadpole shrimps challenge the concept of 'living fossils'. PeerJ, 1:e62; DOI 10.7717/peerj.62.

MATULAITIS, R. 2007. A new location of tadpole shrimp (Triops cancriformis L.) in Lithuania. Acta Zoologica Lituanica, 17 (3): 247-248.

MURA, G. \& N. HADJISTEPHANOU. 1987. First record of Branchinella spinosa (Milne-Edwards) (Crustacea, Anostraca) in Cyprus. Rivista di Idrobiologia, 26: 111-115.

NYLANDER, J. A. A. 2004. MrModeltest v2. Program Distributed by the Author. Evolutionary Biology Centre, Uppsala University.

RUIZ, E. 2008. Management of Natura 2000 habitats. $3170 *$ Mediterranean temporary ponds. European Commission.

SCANABISSI, F., G. ALFONSO, S. BERGAMASCHI \& B. MANTOVANI. 2006. Primo ritrovamento di Lepidurus couesii Packard, 1875 in Italia. Thalassia Salentina, 29: 113-124. 
SCOTT, S. R. \& A. A. GRIGARICK. 1979. Laboratory studies of factors affecting egg hatch of Triops longicaudatus (LeConte) (Notostraca : Triopsidae). Hydrobiologia, 63(2): 145-152.

SU, T. \& M. S. MULLA. 2002. Factors affecting egg hatch of the tadpole shrimp Triops newberryi, a potential biological control agent of immature mosquitoes. Biological Control, 23(1): 18-26.

TSINTIDES, T., C. S. CHRISTODOULOU, P. DELIPETROU, K. GEORGHIOU. 2007. The Red Data Book of the Flora of Cyprus. Cyprus Forestry Association. Cyprus.

VANSCHOENWINKEL, B., M. SEAMAN \& L. BRENDONCK. 2010. Hatching phenology, life history and egg bank size of fairy shrimp Branchipodopsis spp. (Branchiopoda, Crustacea) in relation to the ephemerality of their rock pool habitat. Aquatic Ecology. 44: 771-780.

VANSCHOENWINKEL, B., T. PINCEEL, M. P. M
VANHOVE, C. DENIS, M. JOCQUE, B. V. TIMMS \& L. BRENDONCK. 2012. Toward a global phylogeny of the "Living Fossil" Crustacean Order of the Notostraca. PLoS ONE, 7(4): e34998. doi:10.1371/journal.pone.0034998

WALLOSSEK, D. 1993. The Upper Cambrian Rehbachiella and the phylogeny of Branchiopoda and Crustacea. Fossils and Strata, 32: 1-202.

WATERKEYN, A., B. VANSCHOENWINKEL, P. GRILLAS \& L. BRENDONCK. 2010. Effect of salinity on seasonal community patterns of Mediterranean temporary wetland crustaceans: A mesocosm study. Limnology and Oceanography, 55(4): 1712-1722.

ZACHARIAS, I., E. DIMITRIOU, A. DEKKER \& E. DORSMAN. 2007. Overview of temporary ponds in the Mediterranean region: Threats, management and conservation issues. Journal of Environmental Biology, 28(1): 1-9. 